\title{
Corrigendum: Notch signal strength controls cell fate in the haemogenic endothelium
}

Leonor Gama-Norton, Eva Ferrando, Cristina Ruiz-Herguido, Zhenyi Liu, Jordi Guiu, Abul B.M.M.K. Islam, Sung-Uk Lee, Minhong Yan, Cynthia J. Guidos, Nuria López-Bigas, Takahiro Maeda, Lluis Espinosa, Raphael Kopan \& Anna Bigas

Nature Communications 6:8510 doi: 10.1038/ncomms9510 (2015); Published 14 Oct 2015; Updated 4 Mar 2016

The original version of this Article contained a typographical error in the spelling of the author Zhenyi Liu, which was incorrectly given as Zenhy Liu. This has now been corrected in both the PDF and HTML versions of the Article.

(c) This work is licensed under a Creative Commons Attribution 4.0 International License. The images or other third party material in this article are included in the article's Creative Commons license, unless indicated otherwise in the credit line; if the material is not included under the Creative Commons license, users will need to obtain permission from the license holder to reproduce the material. To view a copy of this license, visit http://creativecommons.org/licenses/by/4.0/ 